\title{
Immunization of Balb/c Mice with Modified Auto- Antigens for Induction of Autoimmune Sialoadenitis
}

\author{
Carmelinda Schmidt UNTERKIRCHER ${ }^{1}$ \\ Mariella Vieira Pereira LEÃO \\ Yasmin Rodarte CARVALHO ${ }^{1}$ \\ ${ }^{1}$ Department of Biosciences and Oral Diagnosis, School of Dentistry of São José dos Campos, \\ São Paulo State University, São José dos Campos, SP, Brazil \\ ${ }^{2}$ Basic Institute of Biosciences, University of Taubaté, Taubaté, SP, Brazil
}

\begin{abstract}
Sjögren's syndrome is an autoimmune disease characterized by sialoadenitis and elevated titers of autoantibodies. To assess whether it is possible to induce inflammatory changes in salivary gland tissues, a series of immunizations in Balb/c mice have been undertaken, using salivary gland extract, modified or not, added to several adjuvants. Mice's humoral immune response to salivary gland antigens was monitored by ELISA. Inflammatory cells infiltrating gland tissue were seen 3 months after immunization with salivary gland extract modified with pepsin (AgGp) and metaperiodate (AgGMp). Although pathological progression was not observed, the histopathological picture was similar to the initial phase of Sjögren's syndrome. In addition, a monoclonal antibody reactive with 3 gland polypeptides and anhydrase carbonic II was rescued among B cells from immunized mice. Thus, immunizations with modified autoantigens were able to initiate pathological damage to glandular tissue and stimulate the proliferation of auto-reactive B cells.
\end{abstract}

Key Words: sialoadenitis, salivary gland, autoimmune disease, carbonic anhydrase.

\section{INTRODUCTION}

Sjögren's syndrome (SS) is an autoimmune disease characterized by sialoadenitis, xerostomia and keratoconjuntivitis sicca. SS patients have serum antibody reactive to different autoantigens (1). One of the most important serological hallmarks of SS is the antibody response to normally inaccessible antigens. These antigens are highly conserved molecules, an usually limited number of cellular proteins among which are the SS-A and SS-B antigens (2-4).

Over the last 10 years, several approaches have been undertaken in order to identify the target antigens in this autoimmune disease. It has been suggested that carbonic anhydrase II may be one of the target antigen for the immunological process in the pathogenesis of various autoimmune exocrinopathies $(5,6)$. Nevertheless, Nishimori et al. (7) did not observe an increased cellular response to carbonic anhydrase II in patients diagnosed with Sjögren's syndrome and idiopathic chronic pancratitis.

The development of animal models for disease research may help these investigations. Previous efforts in this field included the immunization of different animal species with salivary gland extracts in various adjuvants (8). Nevertheless, the insights gained from these studies have not pointed out the molecular nature of the antigens involved.

In order to assess whether it is possible to induce inflammatory changes in salivary gland tissues, a series of immunizations in Balb/c mice have been undertaken, using salivary gland extract, modified or not, added to complete and incomplete Freund's adjuvant. Inflammatory cells infiltrating gland tissue were seen 3 months after the first injection with salivary gland extract modified with pepsin (AgGp) and metaperiodate (AgGMp). In addition, a monoclonal antibody (IgMk) reactive with bovine anhydrase carbonic II and three other gland polypeptides was rescued among B cells from AgG immunized mice.

Correspondence: Profa. Dra. Mariella Vieira Pereira Leão, Instituto Básico de Biociências, Avenida Tiradentes 500, Bom Conselho, 12030-180 Taubaté, SP, Brasil. Tel: +55-12-3635-3466. Fax: +55-12-3921-0573. e-mail: mariellaleao@yahoo.com.br 


\section{MATERIAL AND METHODS}

\section{Gland Antigens Extract (AgG)}

Salivary glands from 8-week-old mice $(\mathrm{n}=10)$ were removed and minced in phosphate-buffered saline pH 7.4 (PBS) containing 1 mM PMSF (phenylmethylsulfonyl fluoride) (Sigma Co., St. Louis, MO, USA) and homogenized on ice for 30 min using a tissue homogenizer. After centrifugation at 500X $\mathrm{g}$ for $30 \mathrm{~min}$, the supernatant was saved and kept at $-20^{\circ} \mathrm{C}$ and the pellet dissolved in $150 \mathrm{mM}$ Tris-Hcl pH 6.8, $6 \mathrm{M}$ urea, $14 \mathrm{mM}$ 2 mercaptoethanol, boiled for $5 \mathrm{~min}$ and incubated overnight at $4^{\circ} \mathrm{C}$. The extract was centrifuged and the supernatant dialyzed against multiple changes of distillate water overnight at $4^{\circ} \mathrm{C}$. The first and last supernatants were mixed, concentrated 4 times by ultrafiltration and conserved frozen at $-20^{\circ} \mathrm{C}$. Protein concentration was measured, in all extracts, using protein-dye binding method and bovine serum albumin as standard (9).

\section{Peptic Digestion}

Gland extract proteins (13 mg) were dialyzed overnight against $0.1 \mathrm{M}$ sodium acetate at $4^{\circ} \mathrm{C}$. The $\mathrm{pH}$ was lowered to 4.5 with $2 \mathrm{M}$ acetic acid. Pepsin (Sigma Co.) was added to give an enzyme-protein ratio of $2 \mathrm{mg} /$ $100 \mathrm{mg}$. The mixture was incubated for $18 \mathrm{~h}$ at $37^{\circ} \mathrm{C}$ and the digestion stopped by raising the $\mathrm{pH}$ to 8.0 with 0.5 $\mathrm{M} \mathrm{NaOH}$. The digest was then dialyzed against PBS for $24 \mathrm{~h}$ at $4^{\circ} \mathrm{C}$. This digest was named AgGp and conserved frozen at $-20^{\circ} \mathrm{C}$.

\section{Metaperiodate Oxidation}

A mild oxidation was performed as suggested by O'shannessy and Wilcher (10). Gland extract proteins (13 mg) were dialyzed overnight against $0.1 \mathrm{M}$ sodium acetate at $4^{\circ} \mathrm{C}$ and the $\mathrm{pH}$ was adjusted to 5.5 with $2 \mathrm{M}$ acetic acid. The solution was kept in an ice bath between 0 and $4^{\circ} \mathrm{C}$. A concentrated sodium metaperiodate solution $(0.5 \mathrm{M})$ was freshly prepared in water, added and rapidly mixed with the proteins to give a final periodate concentration of $1 \mathrm{mM}$. The preparation was immediately placed in an ice bath, in a dark chamber, for $20 \mathrm{~min}$. After this time, an aliquot of a termination agent (sucrose $0.5 \mathrm{M}$ ) was added to a final concentration of 10 $\mathrm{mM}$ and the mixture returned to the ice bath for $5 \mathrm{~min}$.
Then, it was dialyzed against PBS overnight at $4^{\circ} \mathrm{C}$ and kept at $-20^{\circ} \mathrm{C}$. This preparation was named AgMp.

\section{Immunization}

Eight-week-old female Bal/c mice $(\mathrm{n}=20)$ were intradermically injected at 2 sites on the back with 150 $\mu \mathrm{g}$ protein dissolved in $0.1 \mathrm{~mL}$ PBS emulsified in an equal volume of complete Freund's adjuvant (first dose). The subsequent ones were administered in incomplete Freund's adjuvant. After 3 months, the mice were killed and the salivary glands rapidly excised. Control mice only received PBS plus adjuvant.

\section{Histological Assessment}

Salivary glands from immunized and control mice were immediately immersed in $10 \%$ buffered formalin for $24 \mathrm{~h}$ and then embedded in paraffin. Serial 5 - $\mu \mathrm{m}$-thick sections were made along the entire gland length, stained with hematoxylin-eosin and the degree of sialoadenitis was assessed under high microscopy by 3 observers. Scores were obtained and the average scores were calculated from each group for statistical comparison by Kruskal-Wallis test at 5\% significant level.

\section{Hybridoma Production}

Hibridoma was produced as suggested by Goding (11). Five immunized Balb/c mice were allowed resting for 2 months. Three days before fusion, the mice were boosted with $200 \mu \mathrm{g}$ of AgG and the spleen was aseptically removed. Fusion was done using polyethylene glycol as the fusing agent and non-secreting mieloma line Sp2/O-Ag-14 cells. Hybrids were selected in HAT medium (RPMI 1640, 10\% fetal calf serum and HAT supplement; Sigma Co.). After 15 days, supernatants from positive wells were screened by immunoblotting and ELISA on antigen coated plates (Corning Costar Corporation, Cambridge, MA, USA).

Hybrids of interest were cloned by limiting dilution method and subcloned 4 times. Cloned lines were injected into pristane-primed Balb/c mice for generation of ascites fluid. Isotyping of antibodies was performed, after purification in E-Z-Sep - ascites IgG and IgM (Amersham Pharmacia Biotech, Piscataway, NJ, USA) by ELISA with mouse-typer isotyping panel (Bio-Rad Laboratories, Inc., Hercules, CA, USA). 
ELISA

Antigens were used at a concentration of $5 \mu \mathrm{g} / \mathrm{L}$. Polystyrene-flat-bottomed plates (Costar) were coated with antigen diluted in $0.1 \mathrm{M} \mathrm{NaHCO}_{3},(50 \mu \mathrm{L} /$ well $)$ and incubated $2 \mathrm{~h}$, at $37^{\circ} \mathrm{C}$ and overnight, at $4^{\circ} \mathrm{C}$. Peroxidase conjugated goat IgG anti-mouse $\mu, \alpha$, and $\gamma$ chain were used. The reaction was developed with o-phenylenediamine in citrate-citric acid buffer, $\mathrm{pH}$ 5.0. The reaction was stopped with $2.5 \mathrm{M} \mathrm{H}_{2} \mathrm{SO}_{4}$ and the color was measured at $490 \mathrm{~nm}$ in a ELISA reader (3550 modelBio-Rad Laboratories, Inc.).

\section{SDS-PAGE and Western Blotting}

Salivary gland extract, modified or not, were electrophoresed on $10 \%$ polyacrilamide gels as previously described (12). The immunoblotting assay was based on the Towbin's report (13) with some modifications. Briefly, proteins were transferred to Hybond-ECL nitrocellulose membrane (Amersham, Arlington Heights, IL, USA) in a Transblot tank containing $25 \mathrm{mM}$ Tris, $192 \mathrm{mM}$ glicine and $20 \%$ methanol at $50 \mathrm{~V}$ overnight at $4^{\circ} \mathrm{C}$. After transfer, the remaining protein-binding sites were blocked by immersing the membrane in 5\% blocking buffer (5\% skim milk, 0.1\% tween 20 - PBS) for $1 \mathrm{~h}$ at room temperature on a orbital shaker. The membrane was rinsed 3 times with washing buffer (0.1\% Tween 20 -PBS) and incubated for $1 \mathrm{~h}$ with $\mathrm{mAb}$ (C8F) diluted in blocking buffer. After a new washing, a horseradish peroxidase-linked anti-IgM antibody (Sigma

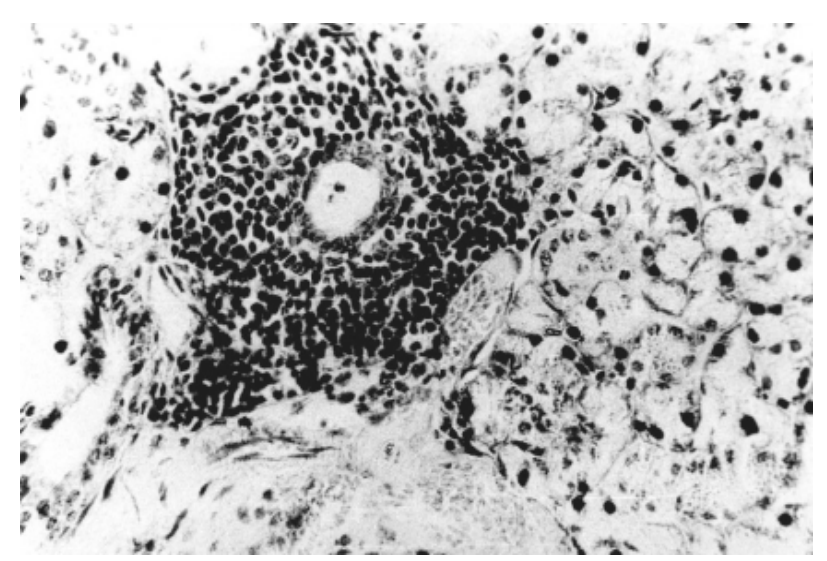

Figure 1. Salivary gland of Balb/c mice immunized with metaperiodate modified antigen. Lymphoid cell infiltration was seen surrounding intralobular ducts.
Co.) $1 \mu \mathrm{g} / \mathrm{mL}$ was used for $1 \mathrm{~h}$. Subsequently, the membrane was washed and the chemiluminescent reagents were added. Light emission was detected by a short exposure to TMG/RA -1 Kodak film in a closed cassette (Cronex intensifying screens; Sigma Co.).

\section{RESULTS}

Mice were immunized with 3 gland extracts and, 3 months later, their salivary glands were harvested and studied for pathological alterations. Random sections of the salivary glands were examined and considered positive (scores between 2 and 4) when they displayed more than one focus of mononuclear cells (MNC). Infiltrates were rare (scores 0 and 1 ) in untreated mice and in mice immunized with non-modified gland extract. The foci were single, discrete and placed in the interlobular connective tissue near the large blood vessels. Positive results were found when immunization was undertaken with antigens modified by metaperiodate and pepsin. In the metaperiodate treated group, large foci of MNC (scores 3 or 4) were observed adjacent to or surrounding intralobular ducts (Fig. 1). The MNC consisted of lymphoblasts, lymphocytes and some plasma cells. In the large foci, the relative number of lymphocytes was greater and the cells were densely packed. In the pepsin treated group, MNC infiltration was also seen, although the foci were smaller (scores 2 or 3 ) and located in the connective tissue between the lobules (Fig. 2). In this experiment, complete Freund's adjuvant administration in the first injection did not

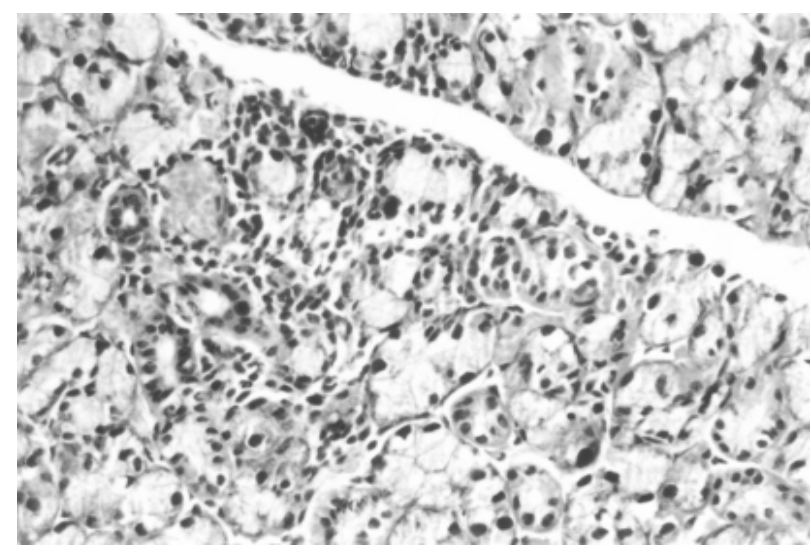

Figure 2. Salivary gland of Balb/c mice immunized with pepsin modified antigen. Lymphoid infiltrates were smaller in size and number and located next to large duct. No compression or atrophy. 
disturb the final results. There were statistically significant differences $(\mathrm{p}<0.05)$ between scores from control group (immunized with adjuvant only) and the group immunized with modified antigens (Fig. 3).

Five hybrids were isolated as a result of fusion. Four of them were IgM. The results of Western blotting studies demonstrated that $\mathrm{mAb} \mathrm{C} 8 \mathrm{~F}$ bound to 3 polypeptides in gland extract and to bovine carbonic anhidrase II (Fig. 4). Binding was stronger in antigens treated by metaperiodate.

\section{DISCUSSION}

This work described the harmful effects of selfrecognition when mice were immunized with modified autoantigens. The approach herein used has showed that pathological changes were directly linked to chemical modification made in autoantigens because no differences were seen when various adjuvants were tried associated to non-modified antigens. In this study, an approach was designed to understand the nature of the antigen that triggers the autoimmune process in Sjögren's syndrome. Our attempt to elucidate a small part of this abnormal pathway was partially successful, especially with metaperiodate treated antigen.

The findings of the present study are in agreement with those of a previous work (8) that reported great success in inducing sialoadenitis in PL/J mice immunized with human carbonic anhydrase II. Tissue

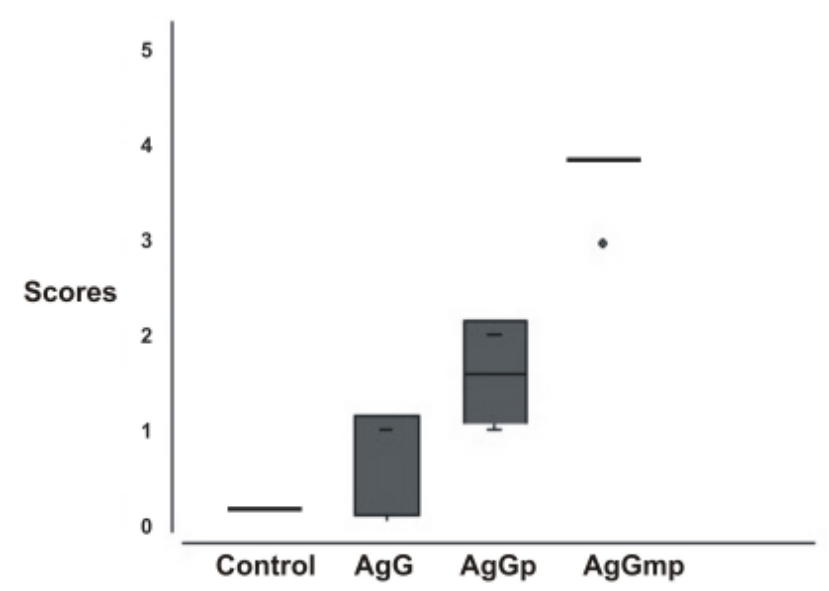

Figure 3.Degrees of sialoadenitis (media of scores) of studied groups assessed by high microscopy. sections from CA II immunized mice showed an increase in the number and size of foci with lymphocytic infiltration in the salivary gland compared with mice immunized with adjuvant alone and untreated mice. It was remarkable that the location of the infiltrates was very similar to that of the present study. However, we were not able to reproduce atrophy and replacement of acinar units. In addition, as other organs such as pancreas and kidney were not examined to obtain more information, it is not possible to state whether they were damaged or not by the procedure.

Searching for a monoclonal autoantibody, it was selected, among B cells from mice immunized with AgG, a hybrid synthesizing a mAb reactive with carbonic anhydrase II and 3 other gland polypeptides. The existence of autoantibodies in SS patients' serum to an antigen expressed in ductal cells of exocrine glands has been shown (14). This antigen was identified to belong to carbonic anhydrase family. Serum antibodies against carbonic anhydrase II have been found in idiopathic chronic pancreatitis and SS patients (15).

The presence of carbonic anhydrase isoforms in salivary glands and human saliva implicates the enzyme in bicarbonate production and suggests that it may contribute to mucosal protection from acid injury (16).

The polypeptides herein observed had molecular weights of about 50,000-68,000, very close to subunit of CA VI, a membrane-bound glycoprotein. As already shown on nitrocellulose sheets, C8F mAb has recog-

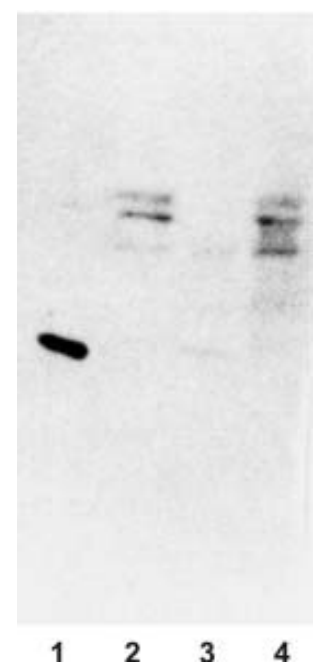

Figure 4. Immunoblotting - C8F reactivity. Lanes: 1 - bovine carbonic anhydrase; 2 - Crude gland extract; 3 - metaperiodate modified gland extract; 4 - pepsin modified gland extract. 
nized the cytoplasmic monomeric enzyme, CA II, from bovine salivary gland. Therefore, it may be suggested that $\mathrm{C} 8 \mathrm{~F} \mathrm{mAb}$ may be recognizing a conserved epitope in all anhydrase isoforms. To confirm this statement, C8F binding to human CA VI from parotid saliva was assessed in this study using immunoblotting assay. The results showed a positive cross-reaction with human CA VI(data not shown). Curiously, pathological changes herein described were mainly found in serous salivary glands, where CA VI is synthesized by acinar cells and secreted into saliva (17).

Therefore, it was possible to induce sialoadenitis in Balb/c mice by immunization with modified autoantigens. Although pathological progression was not observed, the histopathological picture was similar to the initial phase of the Sjögren's syndrome. It was also observed that B cells from immunized mice produced antibodies reactive with anhydrase carbonic II, a possible target antigen of this autoimmune disease.

\section{RESUMO}

A Síndrome de Sjögren é uma doença auto-imune caracterizada por desenvolvimento de sialoadenite e títulos elevados de autoanticorpos. Com o objetivo de induzir alterações inflamatórias no tecido das glândulas salivares foram realizadas várias imunizações em camundongos BALB/c utilizando extratos de glândulas salivares, modificados ou não, em vários adjuvantes. A resposta humoral para antígenos salivares foi monitorada por ELISA. Células inflamatórias infiltrando o tecido glandular foram vistas 3 meses pós-imunização com extrato de glândula salivar modificado com pepsina (AgGp) e metaperiodato (AgGMp). Embora a evolução patológica não tenha sido observada, o quadro histopatológico foi semelhante à fase inicial da Síndrome de Sjögren. Também foi possível notar, a partir das células B dos animais imunizados, a produção de anticorpos monoclonais reativos com 3 polipeptídeos glandulares e anidrase carbônica II. Assim, a imunização com auto-antígenos glandulares modificados foi capaz de iniciar o processo patológico no tecido glandular e induzir a proliferação de células B produtoras de auto-anticorpos.

\section{ACKNOWLEDGEMENTS}

This work was supported by the Foundation for the Development of the São Paulo State University (FUNDUNESP) and the São Paulo State Research Foundation (FAPESP).

\section{REFERENCES}

1. Fox RI. Sjögren's syndrome. In: Textbook of Rheumatology. Kelley WN, Harris ED, Ruddy S, Sledge CB (editors). 5th ed. Philadelphia: Saunders Company; 1997. p. 955-968.

2. Vernables PJW, Charles PJ, Buchanan RRC, Tung YI,
Mumford PA, Schrieber L, Room GRW, Maini RN. Quantitation and detection of isotypes of anti-SS-B antibodies by ELISA and Farr assays using affinity purified antigens. Arthritis Rheum 1986;26:146-155.

3. Tan EM, Chan EKL, Sullivan KF, Rubin RL. Antinuclear antibodies (ANAs): diagnostically specific immune markers and clues toward the understanding of systemic autoimmunity. Clin Immunol Immunopathol 1988;47:121-141.

4. Smith PR, Williams DG, Venables PJW, Maini RN. Monoclonal antibodies to the Sjögren's syndrome associated antigen SS-B (La). J Immunol Methods 1985;77:63-76.

5. Inagaki Y, Jinno-Yoshida Y, Hamasaki Y, Ueki H. A novel autoantibody reactive with carbonic anhydrase in sera from patients with systemic lupus erythematosus and Sjögren's syndrome. J Dermatol Sci 1991;2:147-154.

6. Frulloni L, Bovo P, Brunelli S, Vaona B, Di Francesco V, Nishimori I, et al. Elevated serum levels of antibodies to carbonic anhydrase I and II in patients with chronic pancreatitis. Pancreas 2000;20:382-388.

7. Nishimori I, Eiki M, Morimoto K, Kohsaki T, Okamoto N, Onishi S. Diminished cellular immune response to carbonic anhydrase II in patients with Sjögren's syndrome and idiopathic chronic pancreatitis. JOP J Pancreas (Online) 2004;5:186-192.

8. Nishimori I, Bratanova T, Toshkov I, Caffrey T, Mogaki M, Shibata Y, Hollingsworth A. Induction of experimental autoimmune sialoadenitis by immunization of $\mathrm{PL} / \mathrm{J}$ mice with carbonic anhydrase II. J Immunol 1995;154:4865-4873.

9. Bradford M. A rapid and sensitive method for the quantification of microgram quantities of protein utilizing the principle of protein-dye binding. Anal Biochem 1976;72:248-254.

10. O'Shannessy DJ, Wilcherk M. Immobilization of glycoconjugates by their oligosaccharides; use of hydrazidoderivatized matrices. Anal Biochem 1990;191:1-8.

11. Goding JW. Antibody production by hybridomas. J Immunol Methods 1989;39:285-291.

12. Laemmli UK. Cleavage of structural proteins during the assembly of the head of bacteriophage T4. Nature 1970;227:680-685

13. Towbin H, Staehelin T, Gordon J. Electrophoretic transfer of proteins from polyacrylamide gels to nitrocellulose sheets: procedure and some applications. Proc Natl Acad Sci USA 1979;76:4350-4354.

14. Nishimori I, Yamamoto Y, Okazaki K, Morita M, Odonera M, Kino J, Tamura S, Yamamoto YE. Identification of autoantibodies to pancreatic antigen in patients with idiopathic chronic pancreatitis and Sjögren's syndrome. Pancreas 1994;3:374-381.

15. Ohsaki KJ, Nishimori I, Morita M, Okazaki K, Yamamoto Y, Onishi S, Hollingsworth MA. Serum antibodies to carbonic anhydrase I and II in patients with idiopathic chronic pancreatitis and Sjögren's. Gastroenterology 1996;110:1579-1586.

16. Parkkila S, Parkkila AK, Lehotola J, Reinila A, Sodervik HJ, Rannisto M, Rajaniemi H. Salivary carbonic anhydrase protects gastroesophageal mucosa from acid injury. Dig Dis Sci 1997;42:1013-1019.

17. Fernley RT, Darling P, Alfred R, Wight RD, Coghlan JP. Tissue and species distribution of the secreted carbonic anhydrase isoenzyme. Biochem J 1989;259:91-96.

Accepted February 2, 2006 